\title{
Correction to: Stroke Prevention in Cervical Artery Dissection
}

\author{
Rick Gill ${ }^{1}$. José Biller ${ }^{1}$
}

Published online: 8 January 2022

(c) Springer Science+Business Media, LLC, part of Springer Nature 2022

\section{Correction to: Current Cardiology Reports (2021) 23:182 https://doi.org/10.1007/s11886-021-01603-2}

Reference 1 in the original publication of this article was incorrect. The original article has been corrected.

Publisher's Note Springer Nature remains neutral with regard to jurisdictional claims in published maps and institutional affiliations.

The original article can be found online at https://doi.org/10.1007/ s11886-021-01603-2.

$\triangle$ Rick Gill

rick.gill@lumc.edu

José Biller

jbiller@lumc.edu

1 Department of Neurology, Loyola University Chicago, Stritch School of Medicine, Maywood, IL 560153, USA 